\title{
Multiple Intelligence Based-Education Mewujudkan Indonesia sebagai Bangsa Para Juara
}

\author{
Ziadatul Husnah \\ UIN Sunan Kalijaga, Kota Yogyakarta, Indonesia, Email: \\ zidatulhusna@gmail.com
}

\begin{abstract}
ABSTRAK
Artikel ini membahas tentang pentingnya pendidikan yang berbasis pada kecerdasan majemuk (multiple intelligences). Pendekatan kecerdasan majemuk dalam pendidikan sesuai dengan ruh pendidikan sebagai proses memanusiakan manusia (humanizing human being). Setiap orang seharusnya diperlakukan secara istimewa sebab dia mempunyai potensi berbeda. Karena itu, ukuran kecerdasan sangat dipengaruhi oleh keunikan tiap individu. Kecerdasan majemuk melihat peserta didik dengan sembilan jenis yaitu kecerdasan linguistik, kecerdasan logis-matematis, kecerdasan ritmik-musikal, kecerdasan visual-spasial, kecerdasan kinestetik, kecerdasan intrapersonal, kecerdasan interpersonal, kecerdasan natural, dan kecerdasan eksistensial. Dengan pendekatan ini, proses pendidikan seharusnya dapat mencetak para juara di bidangnya masing-masing.

Kata Kunci: Kecerdasan Majemuk, Pendidikan, Generasi Emas Indonesia
\end{abstract}

\begin{abstract}
This article discusses on the urgence of multiple intelligences-based education. In education, the multiple intelligences approach is very relevant to the spirit of education as a process of humanizing human being. Everyone should be served individually because he/she has different potential. Therefore, indicator of achievement is depended on the individual uniqueness. There is no single indicator on achievement. The multiple intelligences highlightes there are nine kinds of intelligence, namely linguistic intelligence, logical-mathematical intelligence, rythmic-musical intelligence, visual-spatial intelligence, bodilykinesthetic intelligence, intrapersonal intelligence, interpersonal intelligence, natural intelligence, and existential intelligence. Through this approach, the educational process should be able to produce many champions suitable of each potential.
\end{abstract}

Keywords: Multiple Intelligence, Education, Generation of Indonesian Gold.

Article history:

Received: 10-12-2018

Revised: 31-12-2018

Accepted: 20-3-2019 


\section{PEndahuluan}

Generasi emas (golden generation) Indonesia disiapkan menjelang hari ulang tahun kemerdekaan RI yang ke-100 pada tahun 2045. Generasi ini antara lain ditandai oleh individu yang kreatif, inovatif, produktif, berpikir orde tinggi, berkarakter, cinta dan bangga menjadi bangsa Indonesia. Di usia emas ini, bangsa Indonesia diharapkan menjadi kiblat peradaban (center of civilization) di mana semua komponen bangsa mampu menunjukkan karya-karya besarnya. Untuk menuju ke arah tersebut sejak awal harus disiapkan. Alat paling strategis untuk mempersiapkan generasi ini adalah melalui pendidikan berkualitas. Di antara ciri pendidikan berkualitas adalah ketika terjadi proses memanusiakan setiap peserta didik agar menjadi hebat dan juara di bidangnya masing-masing.

Di antara pendekatan dalam pembelajaran yang menarik dan tepat diterapkan untuk mewujudkan generasi unggul adalah yang ditawarkan oleh Howard Gardner yang lebih dikenal dengan pendekatan multiple intelligences (kecerdasan majemuk). Paling tidak ada tiga pertimbangan mengapa tawaran ini tepat untuk mempersiapkan generasi emas. Pertama, konsep kecerdasan majemuk menganggap bahwa setiap individu mempunyai keunikan dan keistimewaan (individual difference). Jika keunikan ini dikembangkan, maka setiap orang dapat menjadi juara sesuai dengan bidangnya masing-masing. Sejauh ini, ukuran kecerdasan yang digunakan dalam konteks pendidikan relatif seragam meskipun ada kecenderungan berubah. Kedua, potensi hebat hakikatnya sudah melekat (embedded) dalam diri tiap orang. Proses pendidikanlah yang menjadikan potensi tersebut berkurang bahkan hilang. Hal ini sebagaimana diungkapkan oleh Gordon Dryden, "all children are born geniuses, and we spend the first six years of their life degeniusing them". Dalam bahasa agama, Rasulullah bersabda, "setiap anak dilahirkan dalam keadaan fitri, orangtuanyalah yang menjadikan anak tersebut berubah [menjadi yahudi, nasrani ataupun majusi]". Ketiga, cara terbaik mempersiapkan generasi emas adalah membiasakan nilai positif sejak kanak-kanak, 
sebab di usia inilah karakter seseorang terbentuk.

Berdasarkan pertimbangan di atas, tulisan ini memfokuskan pada pentingnya pendekatan kecerdasan majemuk dalam konteks pendidikan untuk mewujudkan generasi emas Indonesia tahun 2045. Ada tiga pembahasan dalam artikel ini, yaitu tentang profil generasi emas Indonesia tahun 2045, pentingnya kecerdasan majemuk dalam pendidikan, dan penyiapan generasi juara melalui pendidikan dasar.

\section{METODE PENELITIAN}

Penelitian ini menggunakan paradigma interpretif (interpretive paradigm) dengan pendekatan filosofis, dalam pengertian penulis mencoba mengkaji makna pendidikan secara radikal bahwa pendidikan merupakan proses memanusiakan manusia. Kajian ini dikaitkan dengan paradigma kecerdasan majemuk (multiple intelligences) menurut Gardner yang menurut penulis sangat cocok mengembalikan ruh pendidikan secara filosofis sebagai wujud penghargaan terhadap setiap potensi kemanusiaan peserta didik sehingga setiap orang diperlakukan secara

unik sesuai bidangnya masingmasing. Data dikumpulkan melalui dokumentasi terutama melalui sumber primer terkait dengan konsep pendidikan.

\section{HASIL DAN DISKUSI}

\section{A. Penyiapan Generasi Emas Indonesia 2045}

Imagined

community, meminjam terma dari Ben Anderson (Anderson, 2007: 9-46), yang terjadi pada tahun 2045 adalah tahun prestasi positif ketika bangsa Indonesia merayakan ulang tahun kemerdekaan ke-100. Imajinasi positif kondisi bangsa Indonesia ini menjadi energi positif bagi seluruh rakyat untuk mewujudkan berbagai prestasi yang diperhitungkan dunia internasional. Jika menurut survey dari Rehman dan Askari tahun 2010 tentang negara paling islami Indonesia menempati urutan 140 (Rehman dan Askari, 2010), maka pada tahun 2045, bangsa dengan jumlah penduduk mayoritas Islam ini (diharapkan) benar-benar mewujudkan nilai-nilai Islam, bukan sekedar mempunyai jumlah pemeluk agama Islam. Jika menurut survey UNESCO dalam The Most Literate Nations tahun 2016 dari 61 negara 
yang disurvey tentang minat baca bangsa di dunia Indonesia masuk ranking 2 dari bawah (60) (Kompas, 2017), maka tahun 2045 Indonesia masuk lima besar. Tentu saja ini di antara visualisasi kondisi bangsa Indonesia pada usia emas dipenuhi oleh generasi emas yang mengharumkan nama bangsa. Hal ini dapat diwujudkan jika generasi tahun ini dipersiapkan dengan baik terutama melalui pendidikan.

Prestasi imajiner bangsa Indonesia tersebut merupakan sebuah pengandaian agar Indonesia benar-benar sebagai bangsa unggul, ramah dan gemah ripah loh jinawi. Berbagai 'produk unggulan' bangsa tersebut tidak akan pernah muncul jika kondisi pendidikan di Indonesia belum mendapatkan perhatian seperti saat ini, di mana misi pendidikan telah mengalami misleading. Pendidikan yang mestinya sebagai proses pembebasan manusia dari berbagai penindasan, membentuk kesadaran kritis peserta didik, dan sebagai proses transformasi individu dan masyarakat, malah berubah menjadi proses penghambat berkembangnya potensi kemanusiaan peserta didik, membentuk kesadaran magis dan

naif dalam pandangan Paulo Freire (Freire, 2005: 37-49), dan sebagai proses hegemoni dalam pandangan Antonio Gramsci (Gramsci, 1971: 12-13). Seringkali pendidikan dijadikan sebagai proses penjinakan, kooptasi, dan hegemoni dari penguasa. Banyak individu yang mempunyai potensi hebat justru mati ketika masuk lembaga pendidikan (baca: sekolah). Kata Neil Postman, dalam bukunya The End of Education, peserta didik masuk sekolah dengan tanda tanya (?) dan keluar dengan tanda titik (.) (Postman, 1995).

Kondisi pendidikan ini akan jauh berbeda wajah pada lima puluh tahun mendatang jika para pembuat kebijakan pendidikan dan praktisi pendidikan memahami dan menerapkan kecerdasan majemuk (KM) atau multiple intelligence. Teori yang diusung oleh Howard Gardner sejak dekade 80-an ini banyak menawarkan teori baru tentang makna kecerdasan sebagaimana yang selama ini dipahami. Yang paling mengemuka selama ini, kecerdasan lebih diartikan sebagai kecerdasan intelektual (IQ), meskipun belakangan sudah berkembang kecerdasan emosional 
(emotional intelligence) yang diusung oleh Daniel Goleman (Goleman, 2000) dan kecerdasan spiritual (spiritual intelligence) yang ditawarkan oleh Danah Zohar (Zohar, 2000: 3-38). KM mencoba melihat kecerdasan lebih komprehensif dalam diri setiap orang. Awalnya ada delapan jenis kecerdasan, kemudian Gardner menambah satu jenis kecerdasan lagi (kecerdasan eksistensial), yang ditawarkan KM, yaitu kecerdasan linguistik, logis-matematis, spasial, musikal, kinestetis-jasmani, interpersonal, intrapersonal, dan naturalis. Praktek pendidikan mestinya berupaya mengoptimalkan semua jenis kecerdasan ini, sehingga tidak ada peserta didik yang merasa dirinya bodoh dan tidak bisa apaapa', padahal dalam kenyataannya ada yang salah dengan praktek pendidikan (Gardner, 2006: 8-24).

Dalam konteks kecerdasan majemuk, setiap orang harus dilihat dari sudut pandang potensi dan keunikan masing-masing.

Pendidikan seharusnya mampu memetakan potensi tiap peserta didik dan memberikan perlakuan sesuai dengan potensi sehingga tiap orang dapat menjadi juara di

bidangnya. Dengan demikian, tidak perlu ada kompetisi, apalagi saling menjatuhkan, sebab setiap orang mempunyai kehebatan. Ada sebuah adagium Arab, "la-tahtaqiranna man-dunaka, falikulli sya'in maziyah" (janganlah meremehkan orang yang lebih rendah dari kamu, sebab setiap sesuatu mempunyai keistimewaan sendiri).

\section{B. KM dan Perubahan Paradigma Pendidikan Kontemporer}

Munculnya istilah KM (multiple intelligence) seiring dengan adanya cara dan perspektif baru dalam memandang hakikat, kegiatan dan proses pendidikan. Menurut pandangan baru ini, proses dan pola pembelajaran yang selama ini berlangsung kurang melihat pada hakikat peserta didik dan makna belajar itu sendiri. Selain KM, terma lain sebagai representasi gerakan baru (new movement) ini adalah learning revolution (Dryden and Voz, 1999), quantum learning (DePorter, 1992), brain based learning (Jensen, 1996), superlearning (Ostrander and Schroeder, 1994), creative brain (Herrmann, 1995), active learing (Silberman, 1996), mind map (Buzan, 1993), dan accelerated learning 
(Meier, 2000). Menariknya, berbagai istilah tersebut muncul tidak sekedar sebagai respons tak beralasan (by accidence), namun didukung oleh hasil riset yang mendalam.

Ibarat gayung bersambut, berbagai gagasan baru tersebut sebenarnya saling mendukung dan menyempurnakan. KM muncul sebagai wujud cara pandang baru terhadap hakikat peserta didik yang menjadi pusat perhatian dalam treatment pendidikan. Temuan Gardner ini menempati posisi penting dalam praktek pendidikan kontemporer karena beberapa pertimbangan. Pertama, tawaran tentang KM didasarkan pada berbagai hasil riset mendalam tentang potensi yang dimiliki oleh setiap orang. Menurut teori ini semua anak adalah individu yang berbakat. Tiap-tiap anak terlahir ke dunia ini dengan potensi yang unik, yang jika dipupuk dengan benar, dapat ikut memberikan sumbangan yang lebih baik bagi dunia. Tugas pendidikan, termasuk orang tua dan pendidik, adalah menemukan dan mengembangkan anugerah Tuhan ini. Kedua, Gardner tidak hanya berbicara pada dataran teoritis

tetapi juga praktis, sebab apa yang ditawarkan merupakan hasil praktek di lapangan seperti di American Airlines, Bell Atlantic, Chevron, Consolidated Edison, Florida Community College, Fortune 100 Midwest Manufacturer, Kodak, dan Travelers Insurance. KM banyak dikembangkan oleh Gardner dan koleganya di Harvard Project Zero. Ketiga, gagasan KM dituangkan secara runtut mulai dari filosofinya sampai penerapan praktisnya. Hal ini dilakukan bersama tim yang saling mendukung. Di antara pendukung Gardner adalah Thomas Armstrong yang berupaya menjabarkan lebih rinci teori $\mathrm{KM}$ yang dilontarkan oleh Gardner.

Di tangan Thomas Armstrong, teori KM menjadi sangat praktis dalam dunia pendidikan. Sebab, dia banyak menawarkan hal-hal yang lebih konkret. Dalam salah satu karyanya (Armstrong, 2003), dia mengulas lebih detil tentang KM. paling tidak ada enam hal yang menarik dalam karya Armstrong. Pertama, karyanya memuat hasilhasil riset terbaru Gardner yang meliputi informasi tentang kecerdasan yang ke-8, yakni naturalis, dan kecerdasan yang ke-9, 
yakni eksistensial. Kedua, karya Armstrong mengulas strategi pembelajaran bagi tiap-tiap kecerdasan. Ketiga, berisi cara menyusun kurikulum gaya baru berbasis KM. Keempat, memuat metode delapan cara untuk merancang sistem penilaian dan ujian. Kelima, berisi pengembangan karier dengan pendekatan KM. Terakhir, pendidikan khusus yang terfokus pada kemampuan dan kelebihan, bukan kelemahan. Buku ini sebagai karya seorang pendidik yang telah mengabdikan diri dalam KM selama lebih dari empat belas tahun.

\section{Buku karya Armstrong} menarik dicermati dalam konteks KM karena ditulis oleh orang yang cukup lama berkecimpung dalam dunia pendidikan. Ia adalah seorang penulis dan pembicara yang sudah malang-melintang dan cukup banyak makan garam dalam bidang pendidikan. Ia memiliki pengalaman mengajar lebih dari 28 tahun, mulai dari jenjang pendidikan dasar hingga tingkat doktoral. Dia termasuk penulis prolifik dalam bidang pembelajaran dan pengembangan sumber daya manusia. Berbagai karyanya telah banyak diterjemahkan ke berbagai bahasa, misalnya In Their Own Way, Awakening Your Child's Natural Genius, 7 Kinds of Smart, dan Awakening Genius in the Classroom. Di mata penggagas teori KM, Howard Gardner, Armstrong dikenal dan diakui karena keakuratan laporannya, kejelasan bahasanya, referensinya yang luas, dan cara penyampaiannya yang sangat pas bagi para pendidik.

\section{KM: Penghargaan terhadap Potensi Peserta Didik}

If there are two or more subtopics, the next level of heading (uppercase Roman numerals) should be used, on the other hand, if there are no at least two sub-topics, then no subheadings should be introduced. Styles named "Heading 1," "Heading 2," "Heading 3," and "Heading 4" are prescribed. Teori KM lahir sebagai bentuk revisi atas rumusan cerdas yang dikemukakan oleh Alfred Binet, psikolog asal Prancis, yang beranggapan bahwa kecerdasan dapat diukur secara obyektif dan dapat dinyatakan dengan satu angka atau nilai IQ. Gardner pada dekade 80-an mulai mempertanyakan terma cerdas yang 
sudah berkembang di masyarakat tersebut. Baginya definisi tersebut terlalu sempit. Melalui karya Frames of Mind-nya dia mengemukakan adanya, paling tidak, tujuh kecerdasan dasar yang kemudian ditambah dua jenis kecerdasan lagi menjadi sembilan. Kesembilan jenis kecerdasan itu adalah kecerdasan linguistik, matematis-logis, spasial, musikal, kinestetis-jasmani, interpersonal, intrapersonal, naturalis, dan eksistensial.

Kecerdasan linguistik adalah kemampuan menggunakan kata secara efektif, baik secara lisan (misalnya pendongeng, orator, atau politisi) maupun tertulis (misalnya sastrawan, penulis drama, editor, dan wartawan). Kecerdasan ini meliputi kemampuan memanipulasi tata bahasa atau struktur bahasa, fonologi atau bunyi bahasa, semantik atau makna bahasa, dimensi pragmatik atau penggunaan praktis bahasa. Penggunaan bahasa ini mencakup retorika, mnemonik/hafalan, eksplanasi, dan metabahasa. Kecerdasan matematislogis adalah kemampuan menggunakan angka dengan baik (misalnya ahli matematika, akuntan, ahli statistik) dan melakukan penalaran yang benar (misalnya sebagai ilmuwan, pemrogram komputer, dan ahli logika). Kecerdasan ini meliputi kepekaan pada pola dan hubungan logis dan abstraksi-abstraksi lain. Proses yang digunakan dalam kecerdasan ini antara lain membuat kategorisasi, klasifikasi, pengambilan keputusan, generalisasi, penghitungan, dan pengujian hipotesis.

Kecerdasan spasial adalah kemampuan mempersepsi dunia spasial-visual secara akurat (misalnya sebagai pramuka, pemandu, dan pemburu) dan mentransformasikan persepsi dunia spasial-visual tersebut (misalnya dekorator, desainer interior, arsitek, dan seniman). Kecerdasan ini meliputi kepekaan pada warna, garis, bentuk, ruang, dan hubungan antar unsur tersebut. Kecerdasan ini meliputi kemampuan membayangkan, mempresentasikan ide secara visual atau spasial, dan mengorientasikan diri secara tepat dalam matriks spasial. Kecerdasan kinestetis-jasmani adalah keahlian menggunakan seluruh tubuh untuk mengekspresikan ide dan perasaan (misalnya sebagai aktor, pemain pantomim, atlet, atau penari) dan 
keterampilan menggunakan tangan untuk menciptakan atau mengubah sesuatu (misalnya pengrajin, pemahat, ahli mekanik, atau dokter bedah). Jenis kecerdasan ini meliputi kemampuan fisik yang secara spesifik, seperti melakukan koordinasi, keseimbangan, keterampilan, kekuatan, kelenturan, dan kecepatan maupun menerima rangsangan dan hal lain yang berkaitan dengan sentuhan.

Kecerdasan musikal adalah kemampuan menangani bentukbentuk musikal dengan cara mempersepsi (misalnya sebagai penikmat musik), membedakan (misalnya kritikus musik), menggubah (misalnya komposer), dan mengekspresikan (misalnya penyanyi). Kecerdasan interpersonal merupakan kemampuan mempersepsi dan membedakan suasana hati, maksud, motivasi, serta perasaan orang lain. Kecerdasan ini meliputi kepekaan pada ekspresi wajah, suara, gerak isyarat, kemampuan membedakan berbagai macam tanda impersonal, dan kemampuan menanggapi secara efektif tanda tersebut dengan tindakan pragmatis tertentu. Kecerdasan intrapersonal adalah kemampuan memahami diri sendiri dan bertindak berdasarkan pemahaman tersebut. Kecerdasan ini meliputi kemampuan memahami diri secara akurat (kekuatan dan keterbatasan diri), kesadaran akan suasana hati, maksud, motivasi, temperamen, dan keinginan. Sedangkan kecerdasan naturalis adalah keahlian mengenali dan mengkategorikan spesies, baik flora maupun fauna, di lingkungan sekitar. Dengan delapan jenis kecerdasan tersebut, proses pembelajaran hendaknya dirancang sedemikian rupa sehingga memungkinkan setiap potensi kecerdasan yang dimiliki siswa tersebut berkembang dengan baik.

Secara teoritis, Gardner mengemukakan kriteria yang dapat digunakan untuk dapat disebut cerdas, yang dia bedakan dengan bawaan, kemampuan atau bakat. Pertama, adanya potensi yang terisolasi akibat kerusakan otak. Hal ini ditemukan Gardner ketika ia berinteraksi dengan orang-orang yang pernah mengalami kecelakaan atau memiliki penyakit yang mempengaruhi wilayah otak tertentu. Dari beberapa kasus, terlihat bahwa cedera otak ini 
mengganggu kecerdasan tertentu, tetapi sama sekali tidak mempengaruhi kecerdasan yang lain, misalnya orang yang mengalami cedera pada wilayah broca (lobus kiri depan) akan mengalami gangguan pada kecerdasan linguistiknya sehingga mengalami kesulitan berbicara, menulis, atau membaca, namun ia masih tetap dapat menyanyi, mengerjakan soal-soal matematika, menari, dan menjalin hubungan dengan orang lain. Kedua, adanya savant, genius, dan orang-orang besar lain. Savant adalah individu yang menunjukkan kemampuan superior pada salah satu kecerdasannya, sementara kecerdasan yang lain hanya berfungsi pada tingkat rendah. Sebagai contoh, ada savant yang hanya dapat menggambar dengan sangat bagus, savant yang memiliki memori musik yang sangat mengagumkan, dan savant yang ahli dalam matematika. Ketiga, adanya riwayat perkembangan khusus dan kinerja 'kondisi akhir' bertaraf ahli yang khas. Bagi Gardner kecerdasan terbentuk melalui keterlibatan dalam kegiatan-kegiatan yang bernilai budaya dan bahwa perkembangan seseorang dalam kegiatan tersebut mengikuti pola perkembangan tertentu. Misalnya, kemampuan musik termasuk kegiatan bernilai budaya yang pertama berkembang, kemampuan matematika tidak muncul secepat kemampuan musik, dan kemampuan linguistik mencapai puncak pada usia empat puluhan ke atas. Keempat, adanya sejarah evolusioner dan kenyataan logis evolusioner. Bagi Gardner kedelapan kecerdasan itu memenuhi syarat memiliki akar yang mendalam dalam sejarah evolusi umat manusia dan, evolusi spesies lain, misalnya adanya kecerdasan spasial di guagua atau kecerdasan musikal melalui instrumen musik purba. Kelima, adanya dukungan dari temuan psikometrik. Munculnya tes standar untuk menguji kecerdasan linguistik, spasial, dan kinestetisjasmani, sebagaimana yang dikembangkan oleh Wechsler misalnya, merupakan bukti adanya ragam kecerdasan. Keenam, adanya dukungan dari penelitian psikologi eksperimental. Menurut hasil riset kecerdasan bekerja terpisah satu sama lain, misalnya seseorang yang menguasai kemampuan membaca, 
tetapi gagal menggunakan

kemampuan tersebut di wilayah lain, didik menurut potensinya masingmasing.

seperti matematika. Ketujuh, adanya cara kerja atau rangkaian cara kerja dasar yang teridentifikasi. Akhirnya, adanya kemudahan menyandikannya ke dalam sistem simbol. Salah satu indikator terbaik perilaku cerdas adalah kemampuan manusia menggunakan simbol.

Dengan ditemukannya makna cerdas secara majemuk oleh Gardner dan kawan-kawan tersebut mengharuskan dunia pendidikan harus menata ulang tentang pola dan proses pendidikan yang selama ini berjalan, terutama cara pandang terhadap peserta didik. Sebab, tawaran KM cukup mendasar yang diawali dengan cara pandang terhadap anak. Padahal, praktek pendidikan pada dasarnya berawal dari cara pandang ini. Ketika perspektifnya berubah, maka praktek pendidikannya pun harus menyesuaikan. Perombakan praktek pendidikan tersebut mulai dari pengembangan struktur kurikulum, strategi pembelajaran, pengelolaan kelas, bentuk evaluasi, dan format lembaga pendidikan. Semua perombakan ini dilakukan sematamata untuk memanusiakan peserta

\section{Pembumian KM melalui Pendidikan Dasar: Peluang dan Hambatan}

Untuk konteks keindonesiaan, KM menarik dicermati untuk kemudian dicoba untuk dikembangkan mengingat sudah akutnya problem pendidikan. Meminjam istilah Meier, di Indonesia banyak menderita penyakit pendidikan, mulai dari puritanisme, individualisme, hingga dominannya media cetak. Selain itu, terpuruknya bangsa ini sejak 1997 juga mencerminkan gagalnya proses pendidikan yang selama ini berjalan sehingga tidak mampu mencetak individu-individu cerdas dan tercerahkan yang dapat mengangkat bangsa ini dari keterpurukan. Pendidikan kehilangan elan vital-nya untuk membebaskan manusia dari ketertindasan dan sebagai proses transformasi. Yang terjadi, pendidikan sebagai alat politik penguasa untuk mempertahankan status quo. Karena itu, tidak mengherankan jika banyak "prestasi" atau "gelar" yang diraih bangsa ini, mulai dari minat baca 
paling rendah sampai negara paling korup.

\section{KM termasuk wacana} pendidikan yang baru muncul belakangan, seperti halnya revolusi cara belajar atau kecerdasan emosi. Sebagai wacana baru, banyak di antara praktisi pendidikan yang belum sepenuhnya memahami paradigma baru ini, apalagi mempraktekkan. Karena itu, upaya mendiseminasikan gagasan $\mathrm{KM}$ ini perlu dilakukan secara terusmenerus sehingga tidak berhenti di level wacana saja, namun sampai membumi di tingkatan praxis. Meski demikian, bagaimanapun hebatnya sebuah gagasan, ketika akan diterapkan dalam bentuk praksis, sedikit banyak akan mengalami hambatan. Apalagi dalam konteks pendidikan keindonesiaan, paling tidak ada dua hal yang perlu mendapat perhatian, yakni faktor struktural dan kultural.

Secara struktural, iklim pengelolaan pendidikan di Indonesia masih dibatasi oleh pemerintah pusat. Meskipun sudah berada dalam konteks otonomi dan desentralisasi, namun pemerintah belum sepenuhnya memberikan kebebasan kepada pengelola pendidikan di level bawah untuk berkreasi. Ibarat layang-layang, kadang dilepas penuh tapi kadang dikendalikan. Selain itu, pendidikan seringkali dijadikan sebagai kendaraan politik para elit, sebab pendidikan merupakan media paling efektif untuk membentuk pola pikir dan membangun opini publik. Yang lebih mengerikan lagi, banyak elit politik, termasuk yang menangani pendidikan, tidak mempunyai pengetahuan yang memadai tentang makna pendidikan, sehingga perbaikan bidang ini tidak cukup membawa perubahan yang signifikan, hanya sekedar tambalsulam.

Sebenarnya, munculnya perubahan kurikulum menjadi KBK, dari sisi filosofis "cukup menjanjikan" adanya perubahan. Sebab, kurikulum ini bertolak dari gagasan perlunya menempatkan siswa sebagai subyek pendidikan yang harus dioptimalkan. Semua treatment pendidikan harus untuk melayani kepentingan siswa. Hanya saja, para praktisi pendidikan di level sekolah/madrasah belum sepenuhnya memahami konsep ini. Dengan perubahan kurikulum ini 
memang mengharuskan guru harus lebih aktif dan kreatif menciptakan suasana pembelajaran yang kondusif bagi pengembangan potensi siswa. Guru harus mampu melakukan improvisasi dalam menyampaikan materi tanpa banyak bergantung pada 'juklak' sebagaimana ada dalam era sentralisasi.

Di sisi lain, sukses tidaknya KM dalam praktek pendidikan di Indonesia sangat bergantung juga pada mindset pelaku pendidikan. Hambatan kultural ini sama pentingnya, untuk mengatakan jauh lebih penting ketimbang, hambatan struktural. Merubah kultur tidaklah semudah merubah struktur yang dapat dilakukan dalam waktu sekejap, meskipun kulturnya masih sama dengan struktur lama. Merubah kultur membutuhkan waktu dan proses yang lama, bertahap, dan berkesinambungan.

\section{IV.KESIMPULAN}

Biarkan 100 sekolah KM berkembang. Demikian kata Gardner, sang pencetus teori KM, ketika memberikan pengantar pada karya TA. Bagi Gardner tidak ada sekolah baku dan tunggal untuk menerapkan teori KM. Yang paling penting bagi $\mathrm{KM}$ adalah bagaimana menciptakan sekolah yang dapat menghormati keunikan setiap orang, berbagai variasi cara belajar mereka, sejumlah model untuk menilai mereka, dan cara yang hampir tidak terbatas untuk mengaktualisasikan diri di dunia ini. Tugas utama lembaga pendidikan adalah mengemban misi ini. Karena itu, format sekolah seharusnya fleksibel dan memberikan kesempatan seluas-luasnya bagi setiap anak untuk mengembangkan diri menurut potensinya.

Implikasi dari perspektif ini tentu cukup banyak. Dari sisi pendidik, diperlukan tenaga kependidikan yang memahami dan menghayati betul tentang hakikat manusia, belajar, pendidikan, dan ilmu, sebab tanpa pengetahuan tentang hal ini, praktek pendidikan akan terpuruk lagi. Selain itu, grand design kampus harus mempertimbangkan keunikan siswa, sehingga bentuk kampus tidak boleh hanya berupa gedung yang penuh ruang segi empat (kotakkotak) saja, namun bisa berupa taman, ruang berekspresi, tempat 
bermain, ruang meditasi, dan lain sebagainya yang memungkinkan KM berkembang. Karena itu, konsekuensi berikutnya dari hal ini adalah perlunya fasilitas yang 'lengkap' (representatif) dan untuk dapat menciptakan ini perlu dana yang tidak sedikit. Akhirnya, baik kurikulum, strategi pembelajaran, pengelolaan kelas, dan evaluasi tidak boleh tunggal, namun harus variatif dan fleksibel.

Akhirnya, terlepas dari adanya beberapa hambatan tentang kemungkinan penerapannya di Indonesia, bukan berarti KM ini tidak perlu dikaji. Justru KM dapat dijadikan sebagai pressure ke berbagai pihak untuk menciptakan pendidikan yang menghargai potensi kemanusiaan setiap peserta didik. Untuk itu, berbagai langkah perlu dilakukan, mulai dari membangun opini publik melalui berbagai kegiatan ilmiah seperti diskusi, seminar, dan lokakarya, hingga memberikan masukan kepada para pengambil kebijakan, khsusunya, dan praktisi pendidikan, umumnya, untuk mengambil pesan pokok teori KM ini, meskipun KM bukan satusatunya teori yang harus diambil. Jika langkah ini telah dilakukan dan 64 ada perubahan warna dari praktek pendidikan yang mampu menghargai potensi peserta didik, maka misi karya TA ini telah tercapai. Dalam kerangka inilah, SPJ ini menarik dibaca dan ditindaklanjuti oleh siapapun yang mempunyai komitmen dalam membangun peradaban baru, Indonesia baru, melalui pendidikan sehingga terwujud sebuah bangsa dari para juara.

\section{DAFTAR PUSTAKA}

Anderson, Benedict, 2007. Imagined Communities: Reflections on the Origin and Spread of Nationalism, London \& New York: Verso.

Armstrong, Thomas, 2003. Kecerdasan Majemuk, Mewujudkan Sekolah Para Juara, terj. Fulan, Bandung: Kaifa.

Buzan, Tony, 1993. The Mind Map Book: Radiant Thinking, London: BBC Books.

DePorter, Bobbi, 1992. Quantum Learning, USA: Dell.

Dryden, Gordon and Jeannette Vos, 1999. The Learning Revolution: To Change the Way the World Learns, USA: The Learning Web.

Freire, Paulo, 2005. Education for Critical Consciousness, New York \& London: Continuum. 
Freire, Paulo and Donaldo Macedo, 1987. Literacy: Reading the Word and the World, Great Britain: Routledge \& Kegan Pauld Ltd.

Freire, Paulo, 2005. Pedagogy of the Oppressed, trans. Myra Bergman Ramos, New York \& London: Continuum.

Freire, Paulo, 2000. Pedagogy of the Heart, trans. Donaldo Macedo dan Alexandre Oliveira, New York \& London: Continuum.

Gardner, Howard, 2006. Multiple Intelligences: New Horizon, New York: Basic Books.

Goleman, Daniel, 2000. Emotional Intelligence, Jakarta: Gramedia.

Gramsci, Antonio, 1971. Selection from the Prison Notebooks of Antonio Gramsci, ed. Quintin Hoare and Geoffrey Nowell Smith, New York: International Publishers.

Hermann, Ned, 1995. The Creative Brain, USA: Ned Herrmann Group.

Jensen, Eric, 1996. Brain Based Learning, New York: Turning Point Publishing.
Jones, Steve, 2006. Antonio Gramsci, London \& New York: Routledge.

Kompas tentang budaya literasi bangsa Indonesia edisi tanggal 7 Februari 2017.

Meier, Dave, 2000. The Accelerated Learning Handbook, USA: McGraw-Hill.

Ostrander, Nancy, Shiela Ostrander and Lynn Schroeder, 1994. Superlearning 2000, New York: Delacorte Press.

Postman, Neils, 1995. The End of Education: Redefining the Value of School, USA.

Rehman, Scheherazade S. \& Hossein Askari, 2010. "How Islamic Are Islamic Countries", Global Economy Journal, Berkeley Electronic Press.

Silberman, Mel, 1996. Active Learning: 101 Strategies to Teach Any Subject, Allyn and Bacon.

Zohar, Danah and Ian Marshal, 2000. Spiritual Intelligence: The Ultimate Intelligence, London: Bloomsbury. 